
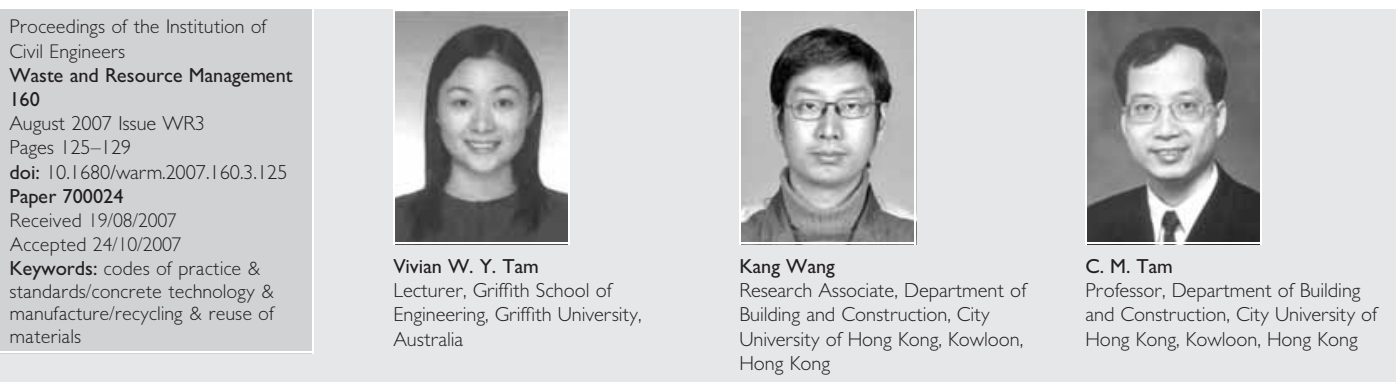

\title{
Ways to facilitate the use of recycled aggregate concrete
}

V. W. Y. Tam PhD, K. Wang BEng and C. M. Tam PhD, FCIOB, MHKIE, FHKICM

A huge amount of solid waste is generated annually from construction and demolition activities. This has led to the promotion of waste recycling as a major measure to reduce waste and to mitigate the harmful effects of construction activities on the environment. Among these wastes, concrete apportions more than half of the total. While recycled concrete waste has been used in low-grade utilisations, high-grade applications are rarely discussed. Although the Hong Kong Special Administrative Region Government has actively been promoting recycling of construction solid waste by issuing technical circulars, specifications and practice notes and setting up a recycling plant to encourage the adoption of recycled aggregate (RA), these measures have not facilitated wide adoption of recycled aggregate concrete (RAC). In fact, the quality of RA and RAC is less than that of virgin material or ordinary concrete and concrete suppliers are thus reluctant to use these materials. Utilising a series of laboratory tests, this paper aims to set out some guidelines to facilitate the use of RAC in the construction industry.

\section{INTRODUCTION}

Construction and demolition (CED) wastes-including demolished concrete (foundations, slabs, columns, floors, etc.), bricks and masonry, wood and other materials such as dry wall, glass, insulation, roofing, wire, pipe, rock and soil ${ }^{1}$-constitute a significant component of total generated waste; recycling of these wastes is thus of great importance. As one of the most effective strategies in waste minimisation, recycling offers three main benefits $^{2-5}$

(a) reduction in demand on new resources

(b) reduction in transport and production energy costs

(c) use of waste that would otherwise be landfilled.

Regarding demand for new resources, the extensive extraction of natural resources for building construction as a result of comprehensive building development and redevelopment plans in most metropolises like Hong Kong has violated the principle of sustainability with increasing objections from environmentalists. ${ }^{6,7}$ To minimise the use of natural resources and the creation of concrete demolition waste, there is a need to develop long-term action plans on the use of materials and to coordinate the various interests of stakeholders and companies in the construction industry. ${ }^{8,9}$ The use of recycled products can reduce the demands for new raw materials; recycled aggregate
(RA) is one of the major construction wastes capable of being recycled and reused. ${ }^{4,10}$ Widespread adoption of RA and the production of recycled aggregate concrete (RAC) is to be encouraged and this paper aims to set out some guidelines to facilitate the use of RA and RAC in Hong Kong.

\section{EFFORTS BY THE HONG KONG GOVERNMENT}

Campaigns on waste reduction have been organised by the Hong Kong Special Administrative Region (SAR) Government in recent years. Construction, as one of the most resourceconsuming industries, ${ }^{11-13}$ has to participate in these campaigns and the use of RA has been strongly advocated as a means of waste minimisation. ${ }^{9,14-17}$ To echo this, the Environment, Transport and Works Bureau issued two technical circularsWaste Management on Construction Sites ${ }^{18}$ and Specifications Facilitating the Use of Recycled Aggregate. ${ }^{19}$ The Hong Kong Housing Authority trialled selective demolition in a school project at Lower Ngau Tau Kok Phase 1 Estate, with the Civil Engineering Department setting up a recycling plant to produce RA in Tuen Mun Area 38 and the Buildings Department issuing a practice note on the use of RA in concrete in February 2003. ${ }^{20}$ Such measures have aimed to promote the adoption of RA along with standards and practice guidelines for its use. As the government's largest building developer in Hong Kong, the Architectural Services Department has started to examine the possibility of using 20\% RA substitution in school construction projects.

\section{RESEARCH METHODOLOGY}

A series of laboratory tests were carried out to assess fresh and hardened concrete properties. Hundreds of mixing trials and concrete cubes were attempted. RA from Tuen Mun Area 38 recycling plant was used in the production of RAC and mixtures of 25, 50, 75 and 100\% RA were tested with designated mix proportions according to Buildings Department specifications ${ }^{20}$ (see Table 1) with a water/cement ratio of $0 \cdot 45$. Standards used to test the properties of RA and RAC are summarised in Table $2 .^{21-35}$ It should be noted that the properties of recycled coarse aggregate and recycled fine aggregate are different. In this study, recycled coarse aggregate was used for the experimental work.

\section{MAJOR FINDINGS}

\section{I. Potential reduction in RAC quality}

The main difference between RA and ordinary aggregate is that RA contains some cement mortar as a result of crushing concrete 


\begin{tabular}{lc}
\hline Concrete ingredients & Mass: kg \\
\hline Ordinary Portland cement & 100 \\
Fine aggregate & 180 \\
$20 \mathrm{~mm}$ coarse aggregate & 180 \\
$10 \mathrm{~mm}$ coarse aggregate & 90
\end{tabular}

Table I. Mix proportions

waste. ${ }^{35}$ This residual cement mortar changes the concrete properties $^{37-39}$ and degrades targets on density, strength, rigidity, deformation and permeability. From the experimental results, significant reductions were found with different proportions of added RA, as shown in Table 3. The reduction percentage can be measured by equation (1).

\begin{tabular}{|c|c|}
\hline I & {$\left[\left(N_{d}^{r}-N_{d}^{r 0}\right) / N_{d}^{r 0}\right] \times 100 \%$} \\
\hline
\end{tabular}

where $N_{d}^{r 0}$ is the result for different RAC properties collected with $0 \%$ RA substitution on day $d$ and $N_{d}^{r}$ is the result for different RAC properties collected with $r \%$ RA substitution on day $d$. RAC thus needs to be used with care and users should fully understand the behaviour of RAC with an appropriate mix design to cater for these weaknesses.

\subsection{Classification of RA for various applications}

As the quality of RA varies from site to site, it is worth considering the advantages of its production at a centralised recycling plant. $\operatorname{Tam}^{40}$ attempted to correlate various properties of RA. It was found that there exist some relationships between

\begin{tabular}{|c|c|}
\hline Property & Standard \\
\hline \multicolumn{2}{|l|}{ Aggregate } \\
\hline Sieve analysis & BS $882^{21}$ \\
\hline $\begin{array}{l}\text { Particle density on oven-dried } \\
\text { basis }\end{array}$ & BS 812: Part $2^{22}$ \\
\hline $\begin{array}{l}\text { Particle density on saturated } \\
\text { and surface-dried basis }\end{array}$ & BS 812: Part $2^{22}$ \\
\hline Apparent particle density & BS 812: Part $2^{22}$ \\
\hline Water absorption & BS 812: Part $2^{22}$ \\
\hline Moisture content & BS 812: Part $109^{23}$ \\
\hline Flakiness index & BS 812: Part $105-1^{24}$ \\
\hline Elongation index & BS 812: Part $105-2^{25}$ \\
\hline Ten per cent fines value (TFV) & BS 812: Part II $\left.\right|^{26}$ \\
\hline Aggregate impact value (AIV) & BS 812: Part $112^{27}$ \\
\hline Chloride content & BS 812: Part $117^{28}$ \\
\hline Sulphate content & $\begin{array}{l}\text { Manual of Alltech lon } \\
\text { Chromatography System } \\
\text { ICM-300 }\end{array}$ \\
\hline \multicolumn{2}{|l|}{ Concrete } \\
\hline Density & Mass/volume \\
\hline Compressive strength & BS 1881: Part $116^{29}$ \\
\hline Flexural strength & BS 1881: Part $118^{30}$ \\
\hline Tensile splitting strength & BS 1881: Part $1 \mid 7^{31}$ \\
\hline Static modulus of elasticity & BS I88I: Part $|2|^{32}$ \\
\hline Shrinkage & BS 1881: Part $5^{33}$ \\
\hline Creep & ASTM C $512-02^{34}$ \\
\hline Air permeability & Manual of P-6000 Poroscope \\
\hline Water permeability & Manual of GWT-4I70 kit \\
\hline Chloride permeability & AASHTO T277 35 \\
\hline
\end{tabular}

the various properties of RA

\begin{tabular}{|l|l|}
\hline 2 & $W A_{10}=-23 \cdot 855 S S D_{10}+63 \cdot 147\left(R^{2}=0 \cdot 9163\right)$ \\
\hline 3 & $W A_{20}=-21 \cdot 387 S S D_{20}+57 \cdot 04\left(R^{2}=0.9603\right)$ \\
\hline
\end{tabular}

\begin{tabular}{|l|l|}
\hline 4 & $M C_{10}=-4 \cdot 4417 S S D_{10}+11 \cdot 83\left(R^{2}=0 \cdot 7527\right)$ \\
\hline
\end{tabular}

\begin{tabular}{|l|l|}
\hline 5 & $M C_{20}=-4 \cdot 1345 S S D_{20}+11 \cdot 044\left(R^{2}=0 \cdot 7919\right)$ \\
\hline
\end{tabular}

\begin{tabular}{|l|l|}
\hline 6 & $S S D_{10}=0.014 F I_{10}+2 \cdot 1644\left(R^{2}=0.6832\right)$ \\
\hline 7 & $S S D_{20}=0.0139 F I_{20}+2.2232\left(R^{2}=0.7857\right)$ \\
\hline
\end{tabular}

\begin{tabular}{|l|l|}
\hline 8 & $W A_{10}=-0.3199 F I_{10}+11 \cdot 287\left(R^{2}=0.5743\right)$ \\
\hline
\end{tabular}

\begin{tabular}{|l|l|}
\hline & $W A_{20}=-0.3088 F I_{20}+9 \cdot 6472\left(R^{2}=0 \cdot 8188\right)$ \\
\hline
\end{tabular}

where $W A_{10}$ is the water absorption rate for $10 \mathrm{~mm}$ aggregate (in units of \% of dry mass), $S S D_{10}$ is the value of particle density based on the $S S D$ basis for $10 \mathrm{~mm}$ aggregate (in $\mathrm{Mg} / \mathrm{m}^{3}$ ), $W A_{20}$ is the water absorption rate for $20 \mathrm{~mm}$ aggregate (in $\%$ of dry mass), $M C_{10}$ is the moisture content for $10 \mathrm{~mm}$ aggregate (in \% of dry mass), $M C_{20}$ is the moisture content for $20 \mathrm{~mm}$ aggregate (in \% of dry mass), $S S D_{20}$ is the value of particle density based on the SSD basis for $20 \mathrm{~mm}$ aggregate (in $\mathrm{Mg} / \mathrm{m}^{3}$ ), $F I_{10}$ is the flakiness index for $10 \mathrm{~mm}$ aggregate (in \%) and $F I_{20}$ is the flakiness index for $20 \mathrm{~mm}$ aggregate.

Five tests-grain-size qualification, water absorption, 10\% fines value, chloride content and sulphate composition-are adequate to describe the quality of RA (see Table 4). These five tests portray RA behaviour and define RAC applications such as structural element, minor structural element, non-structural element, prestressed concrete element, road surface, insulation barrier, base course and embankment and fill. The requirements for various construction applications are shown in Table $5,{ }^{21,41,42}$ which are equally applicable to the use of virgin materials.

\subsection{Slump loss of RAC}

When using RA to produce RAC, workability needs to be considered. In current practice, if the correct slump cannot be achieved on site, the load of concrete is unacceptable for use, is returned to the batching plant and finally dumped as waste.

Slump loss is loss of consistency in fresh concrete with elapsed time. Slump loss is a normal phenomenon in all concrete because it results from gradual stiffening and setting of hydrated Portland cement paste, which is associated with the formation of hydration products such as ettringite and calcium silicate hydration. ${ }^{43}$ Slump loss occurs when the free water from a concrete mixture is 


$\begin{array}{llll}25 & 50 & 75 & 100\end{array}$

Density reduction ${ }^{* \dagger}: \%$

Compressive strength reduction ${ }^{* \dagger}: \%$

Flexural strength reduction ${ }^{* \dagger}: \%$

Tensile splitting strength reduction ${ }^{* \dagger}: \%$

Modulus of elasticity reduction ${ }^{* \dagger}: \%$

Shrinkage increase ${ }^{\ddagger \dagger}: \%$

Creep increase ${ }^{\ddagger \dagger}: \%$

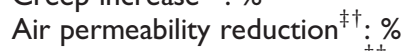

Water permeability increase ${ }^{\ddagger \dagger}$ : \%

Chloride permeability increase ${ }^{\ddagger \dagger}: \%$

$0-1 \cdot 4$
$0 \cdot 3-31 \cdot 8$
$0-10 \cdot 4$
$10 \cdot 6-50 \cdot 7$
$6 \cdot 16-22 \cdot 7$
$0 \cdot 4-30 \cdot 9$
$33 \cdot 13-47 \cdot 26$
$0-26 \cdot 47$
$0-23 \cdot 52$
$0-23 \cdot 70$

$0 \cdot 12-2 \cdot 4$

I.2-57.8

$0-8 \cdot 1$

$12 \cdot 84$

2.8-30.5

$0 \cdot 1-53 \cdot 4$

-

-

-
$1 \cdot 11-10$

$1 \cdot 49-86 \cdot 4$

$8 \cdot 1-20$

$6-29.95$

$1 \cdot 1-50$

$5 \cdot 9-88$

166.47-215.75

$0-57 \cdot 41$

$0-28.84$

$0-30 \cdot 25$

* Tests conducted at 28 days curing

*Tests conducted at $7-56$ days curing

${ }^{\ddagger}$ Tests conducted at 14-182 days curing

${ }^{\dagger}$ Data collected from previous research

Table 3. Reduction of RAC quality with respect to RA ratio

\begin{tabular}{|ll}
\hline Classification method & $\begin{array}{l}\text { Experimental work covered by } \\
\text { classification }\end{array}$ \\
\hline $\begin{array}{ll}\text { Grain-size qualification } & \text { Grain-size qualification } \\
\text { Water absorption } & \text { - Particle density } \\
\text { - Water absorption }\end{array}$ \\
TFV & - TFV Agress index \\
Chloride content & $\begin{array}{l}\text { Chloride content } \\
\text { Sulphate content }\end{array}$ \\
Sable 4. Classification system used to replace experimental work
\end{tabular}

removed by hydration reactions, by adsorption on the surfaces of hydration products and by evaporation. RAC has a higher slump loss than normal aggregate concrete due to the high absorptive rate of the cement portion attached to the RA.

Experimentation confurmed this phenomenon. ${ }^{40}$ For normal aggregate concrete, slump loss is not significant during the first $2 \mathrm{~h}$ of placing time, but becomes more important (with around $50 \mathrm{~mm}$ loss or more) when the concrete placing time is up to $5 \mathrm{~h}$. For RAC, the slump loss during the first $2 \mathrm{~h}$ is around $30 \mathrm{~mm}$ or more and can reach $70 \mathrm{~mm}$ or even up to $150 \mathrm{~mm}$ when the placing time is prolonged.
Although RAC has a higher slump loss, the loss can be reduced if the RA is pre-soaked to a fully saturated condition. The following two procedures are thus recommended when using RAC.

(a) RA should be fully pre-soaked for at least $24 \mathrm{~h}$ before use to obtain the fully saturated condition.

(b) The slump loss for RAC should be considered beforehand and allowed for in the design mix.

\section{COMPARISON OF GOVERNMENT PRACTICE NOTES AND RECOMMENDED GUIDELINES}

Although the Hong Kong Government Buildings Department issued a practice note on the use of recycled aggregate in concrete in February $2003,{ }^{20}$ the information provided is not sufficiently comprehensive for construction professionals to avoid all the uncertainties in the adoption of RAC. Table 6 compares the differences between the requirements of the current government practice note and recommended guidelines.

\section{CONCLUSION}

In recent years, the Hong Kong SAR Government has promoted the adoption of RA and RAC with the issuance of technical circulars, specifications and practice notes and the construction of a recycling plant to produce RA. However, these measures do not provide sufficient background information and knowledge on RAC to allow practitioners to avoid all the uncertainties in RAC use. With the poor quality associated with RA and RAC, concrete

\begin{tabular}{|c|c|c|c|c|c|c|c|c|}
\hline Property & $\begin{array}{l}\text { Structural } \\
\text { element }\end{array}$ & $\begin{array}{l}\text { Minor } \\
\text { structural } \\
\text { element }\end{array}$ & $\begin{array}{l}\text { Non- } \\
\text { structural } \\
\text { element }\end{array}$ & $\begin{array}{c}\text { Prestressed } \\
\text { concrete } \\
\text { element }\end{array}$ & $\begin{array}{c}\text { Road } \\
\text { surface }\end{array}$ & $\begin{array}{l}\text { Insulation } \\
\text { barrier }\end{array}$ & $\begin{array}{l}\text { Base } \\
\text { course }\end{array}$ & $\begin{array}{c}\text { Embankment } \\
\text { and fill }\end{array}$ \\
\hline Grain-size qualification & Ref. 2I & Ref. 2I & Ref. 2I & Ref. 2I & Ref. 4I & Ref. 2I & Ref. 42 & Ref. 42 \\
\hline Maximum water absorption: \% & $5^{*}$ & 10 & 10 & 10 & \multicolumn{2}{|c|}{10} & \multicolumn{2}{|r|}{10} \\
\hline Minimum TFV ${ }^{24}: \mathrm{kN}$ & 150 & 100 & 50 & 100 & \multicolumn{2}{|c|}{100} & \multicolumn{2}{|r|}{50} \\
\hline Maximum chloride content ${ }^{26}: \%$ & 0.05 & 0.05 & I & 0.015 & \multicolumn{2}{|c|}{0.05} & \multicolumn{2}{|r|}{0.05} \\
\hline Maximum sulphate content: \% & I & I & I & 1 & \multicolumn{2}{|c|}{ I } & \multicolumn{2}{|r|}{ I } \\
\hline
\end{tabular}




\begin{tabular}{|c|c|c|}
\hline & Government practice note & Recommended guidelines \\
\hline $\begin{array}{l}\text { Tests required for classification } \\
\text { system }\end{array}$ & $\begin{array}{l}\text { - Particle density } \\
\text { - Water absorption } \\
\text { - Content of wood and other materials } \\
\text { - Content of other foreign materials } \\
\text { - Fines particles } \\
\text { - Content of sand } \\
\text { - Content of sulphate } \\
\text { - Flakiness index } \\
\text { - TFV } \\
\text { - Grading } \\
\text { - Chloride content }\end{array}$ & $\begin{array}{l}\text { - Grading } \\
\text { - Water absorption } \\
\text { - TFV } \\
\text { - Chloride content } \\
\text { - Sulphate content }\end{array}$ \\
\hline Slump requirement & Min. $75 \mathrm{~mm}$ & $\begin{array}{l}\text { Min. } 75 \mathrm{~mm} \text { but higher slump recommended for } \\
\text { RAC made from water-sprayed RA in contrast to } \\
\text { fully soaked RA }\end{array}$ \\
\hline Slump loss & - & $\begin{array}{l}\text { To consider the effects of slump loss for RAC } \\
\text { (both for fully soaked or water-sprayed RA) }\end{array}$ \\
\hline Mix proportioning & Designated mix only & Allow for designed mix \\
\hline Quality of RAC & - & $\begin{array}{l}\text { Highlight changes in quality of RAC in different } \\
\text { proportions of RA }\end{array}$ \\
\hline $\begin{array}{l}\text { Percentage of RA to replace } \\
\text { natural aggregate }\end{array}$ & $\begin{array}{l}20 \% \text { for structural and } 100 \% \text { for non-structural } \\
\text { elements }\end{array}$ & From $0-100 \%$ \\
\hline Types of RAC application & Structural and non-structural & $\begin{array}{l}\text { Structural, minor-structural, non-structural, pre- } \\
\text { stressed concrete, road surface, insulation barrier, } \\
\text { base course, and embankment and fill }\end{array}$ \\
\hline
\end{tabular}

suppliers lack confidence to use these materials. This paper has recommended some guidelines in the use of RAC and has

(a) highlighted potential reductions in RAC quality

(b) classified RA for various construction applications

(c) alerted users to possible extra slump loss in the use of RAC.

A comparison table between the current Government practice note and recommended guidelines is provided for easy reference.

\section{ACKNOWLEDGEMENTS}

The work described in this paper was fully supported by a grant from the Housing Authority Research Fund of the Hong Kong Special Administrative Region, China (Project Ref. No. 9460004).

\section{REFERENCES}

1. Coventry S. The Reclaimed and Recycled Construction Materials Handbook. Construction Industry Research and Information Association, London, 1999.

2. DhiR R. K., LimbachiYa M. C. and Leelawatt T. Suitability of recycled concrete aggregate for use in BS 5328 designated mixes. Proceedings of the Institution of Civil Engineers, Structures and Buildings, 1999, 134, No. 3, 257-274.

3. Dhir R. K., Paine K. A., Dyer T. D., Tang M. C. and Cui Y. Value added recycling of domestic, industrial and construction arisings as concrete aggregate, Concrete Engineering International, 2004, 8, No. 1, 43-48.

4. EDWARDS B. Sustainable Architecture: European Directives and Building Design. Architectural Press, Oxford, 1999.

5. Etxeberria M., Mari A. R. and Vazquez E. Recycled aggregate concrete as structural material. Materials and Structures, 2007, 40, No. 5, 529-541.

6. YAng Y. F. and Han L. H. Compressive and flexural behavior of recycled aggregate concrete filled steel tubes under short-term loadings. Steel and Composite Structures, 2006, 7, No. 3, 257-284.

7. YANG Y. F. and HAN L. H. Experimental behaviour of recycled aggregate concrete filled steel tubular columns. Journal of Construction Steel Research, 2006, 62, No. 12, 1310-1324.

8. Dhir R. K., Dyer T. D. and Paine K. A. Appropriate use of sustainable construction materials. Concrete Journal, 2006, 40, No. 9, 20-24.

9. TORRING M. Management of concrete demolition waste. In Concrete Technology for a Sustainable Development in the 21st Century. E Et F N Spon, London, 2000, pp. 321-331.

10. Corinaldesi V. and Moriconi G. Behavior of beam-column joints made of sustainable concrete under cyclic loading. ASCE Journal of Materials in Civil Engineering, 2006, 18, No. 5, 650-658.

11. Clements R. Complete Guide to ISO 14000. Prentice-Hall, Englewood Cliffs, NJ, 1996.

12. LI W. Composition Analysis of Construction and Demolition Waste and Enhancing Waste Reduction and Recycling in the Construction Industry in Hong Kong. Department of Building and Real Estate, Hong Kong Polytechnic University, 2002.

13. Poon C. S. Management and recycling of demolition waste in Hong Kong. Proceedings of the 2nd International Conference on Solid Waste Management, Taipei, 2000, 433-442.

14. Coluins R. J. Reuse of demolition materials in relation to specifications in the UK, demolition and reuse of concrete and masonry, guidelines for demolition and reuse of concrete and masonry. Proceedings of the $3 \mathrm{rd}$ International RILEM Symposium on Demolition and Reuse of Concrete Masonry, Odense, Denmark, 1993, 49-56. 
15. Construction Industry Research AND InFORMATION Association. Environmental Issues in Construction: A Review of Issues and Initiatives Relevant to the Building, Construction and Related Industries. CIRIA, London, 1993.

16. Hendriks C. F. and Pietersen H. S. Sustainable Raw Materials: Construction and Demolition Waste. RILEM, Cachan, 2000.

17. MulHeron M. The recycling of demolition debris, current practice, products and standards in the United Kingdom. In Demolition and Reuse of Concrete and Masonry: Reuse of Demolition Waste. Chapman and Hall, London, 1988, pp. 510-519.

18. EnVIRonment, Transport and Works Bureau. Waste Management on Construction Sites. Environment, Transport and Works Bureau, Hong Kong Special Administrative Region, China, 2003, ref. 15/2003.

19. EnVIRonment, TRANSPORT ANd Works Bureau. Specifications Facilitating the Use of Recycled Aggregate. Environment, Transport and Works Bureau, Hong Kong Special Administrative Region, China, 2002, ref. 12/2002.

20. Hong Kong Government Buildings Department. Use of Recycled Aggregates in Concrete: Practice Note for Authorized Persons and Registered Structural Engineers. Hong Kong Government, 2003.

21. BRitish Standards Institution. Specification for Aggregates from Natural Sources for Concrete. BSI, London, 1992, BS 882.

22. BRITISH STANDARDS InSTITUTION. Methods for Determination of Density. BSI, London, 1995, BS 812: Part 2.

23. British Standards Institution. Method for Determination of Moisture Content. BSI, London, 1990, BS 812: Part 109.

24. British Standards Institution. Flakiness Index. BSI, London, 1989, BS 812: Part 105-1.

25. BRITISH StANDARDS InStitution. Elongation Index of Coarse Aggregate. BSI, London, 1989, BS 812: Part 105-2.

26. BRtTish StANDARDS Institution. Methods for Determination of Ten Per Cent Fines Value (TFV). BSI, London, 1990, BS 812: Part 111

27. BRITISH StANDARDS InSTITUTION. Methods for Determination of Aggregate Impact Value (AIV). BSI, London, 1990, BS 812: Part 112.

28. BRItish Standards Institution. Methods for Determination of Water-soluble Chloride Salts. BSI, London, 1988, BS 812: Part 117.

29. BRITISH StANDARDS InSTITUTION. Method for Determination of Compressive Strength of Concrete Cubes. BSI, London, 1983, BS 1881: Part 116.

30. BRitish StANDARDS Institution. Method for Determination of Flexural Strength. BSI, London, 1983, BS 1881: Part 118.
31. British StAndards InStTTUTION. Method for Determination of Tensile Splitting Strength. BSI, London, 1988, BS 1881: Part 117.

32. BRITISH StANDARDS InSTITUTION. Method for Determination of Static Modulus of Elasticity in Compression. BSI, London, 1983, BS 1881: Part 121.

33. BRITISH StandARDS InStITUTION. Determination of Changes in Length on Drying and Wetting. BSI, London, 1970, BS 1881: Part 5.

34. American Society for Testing and Materials. Standard Test Method for Creep of Concrete in Compression. ASTM, Philadelphia, 2002, ASTM C512-02.

35. American Association of State Highway and Transportation Officials. Rapid Determination of the Chloride Permeability of Concrete. AASHTO, Washington, DC, 1983, AASHTO T277.

36. Hansen T. C. Recycling of Demolished Concrete and Masonry: Report of Technical Committee 37-DRC, Demolition and Reuse of Concrete. The International Union of Testing and Research Laboratories for Materials and Structures. E \& F N Spon, London, 1992.

37. BarRa M. and VAZQuez E. Properties of concretes with recycled aggregates: influence of properties of the aggregates and their interpretation. Proceedings of the International Symposium on Sustainable Construction, Use of Recycled Concrete Aggregate (eds. DHIR R. K., HENDERSON N. A. and LimbachiYA M. C.). Thomas Telford, London, 1998, pp. 19-30.

38. Dhir R. K., Paine K. A. and Dyer T. D. Recycling construction demolition materials in concrete. Concrete Journal, 2004, 38, No. 3, 25-28.

39. LimbachiYa M. C., DhiR R. K. and LeELAwatt T. Use of recycled concrete aggregate in high strength concrete. Materials and Structures, 2000, 33, No. 9, 574-580.

40. TAM W. Y. V. Recycled Aggregate from Concrete Waste for Higher Grades of Concrete Construction. Department of Building and Construction, City University of Hong Kong, 2005.

41. American Society for Testing and Materials. Standard Classification for Sizes of Aggregate for Road and Bridge Construction. ASTM, Philadelphia, 2003, ASTM D448-03a.

42. American Society for Testing and Materials. Standard Specification Graded Aggregate Material for Base and Subbases for Highway or Airports. ASTM, Philadelphia, 2003, ASTM D2940-03.

43. Mehta P. K. and Monteiro J. M. Concrete: Structure, Properties, and Materials. Prentice-Hall, Englewood Cliffs, NJ, 1993.

\footnotetext{
What do you think?

To comment on this paper, please email up to 500 words to the editor at journals@ice.org.uk
}

Proceedings journals rely entirely on contributions sent in by civil engineers and related professionals, academics and students. Papers should be $2000-5000$ words long, with adequate illustrations and references. Please visit www.thomastelford.com/journals for author guidelines and further details. 